\title{
The State, All at Sea: Interoperability and the Global Network of Navies
}

\author{
Jason Dittmer \\ Department of Geography \\ University College London \\ Pearson Building \\ Gower Street \\ London WC1E 6BT \\ United Kingdom \\ j.dittmer@ucl.ac.uk \\ +4402076790412
}

\begin{abstract}
The sea has long been envisioned as antithetical to land, and therefore geography and the state. The Global Network of Navies (GNoN) is a Pentagon-led program that seeks to extend state power over the seas by cultivating naval interoperability. Interoperability has been a source of American military might since World War 2, but took on heightened importance after the Cold War. In this paper, I make three related arguments. First, I argue that the GNoN is an attempt to produce ocean space within a U.S.-led, but ultimately transnational, state assemblage. Second, I argue that this project relies on the materiality of the sea to affectively nudge forward transnational cooperation. Third, I argue that this reliance on the materiality of the sea is paradoxical, as the GNoN attempts (and ultimately fails) to dematerialize ocean space into abstract network ontology. To make these arguments, I first theorize interoperability through assemblage, highlighting how a transnational state assemblage emerges that works through, but is not reducible to, individual states. I then trace a genealogy of maritime space, showing how maritime space was assembled with U.S. naval technologies and strategies in the nineteenth and twentieth centuries, culminating in the GNoN. Next, I examine the technical challenges of naval interoperability, focusing on C4ISR technologies. The sea's materially limits flows of data that have become synonymous with today's warfighting. Many of the Pentagon's potential partners lack the high-end technology required to be interoperable with the U.S. The C4ISR technology that is therefore distributed to partners is both technical and political; the U.S. remains central to data fusion and distribution. I then return to the sea itself, showing how the GNoN tries to dematerialize the sea but ultimately runs aground on the shoals of materiality. What remains is a smaller, fragmented spatiality that remains oriented around specific seas.
\end{abstract}

Acknowledgements: This paper was first presented at the University of Glasgow at the Geographies of Violence workshop. I would like to thank Kate Hall, Alan Ingram, and Andrew Barry for comments on an earlier draft. Special thanks are due to Arleen Dittmer for introducing me to the interviewees. While these interviewees have been anonymized, I would like to nevertheless publicly thank them for taking the time to sit for interviews.

Author bio: Jason Dittmer is Professor of Political Geography at University College London, where he studies diplomacy, more-than-human assemblages, and geopolitics. His most recent books are Diplomatic Material: Affect, Assemblage, and Foreign Policy (2017, Duke University Press) and Captain America and the Nationalist 
Superhero: Metaphors, Narratives, and Geopolitics (2013, Temple University Press), and Popular Culture, Geopolitics, and Identity (2010, Rowman and Littlefield). He is also the editor (or co-editor) of five volumes, including Geopolitics: an Introductory Reader (2014, Routledge).

\section{Introduction}

Recently geographers have begun to wrestle with the terrestrial bias of the discipline, as approximately $70 \%$ of the earth's surface - the sea - has been neglected by decades of scholarship (see Steinberg, 1999; 2001; 2009). Steinberg and Peters (2015: 249) highlight as exemplary of this neglect Carl Schmitt's (2003) dismissal of 'inconsequential' ocean space:

Schmitt's denigration of the ocean is rooted in his perception of its (im)materiality. He argues that the control of place, its transformation into property, and the communication and fortification of that property's limits through fences and boundaries are impossible in the unknowable, uninscribable, and uncontrollable space of the ocean.

This sense of the ocean as antithetical to terrestrial geography pervades much work, and states themselves have frequently struggled to fit the sea into their territorial framework (Hannigan, 2016). The shore serves as a limit point for the abilities of states to extend their reach. Indeed, the original three-mile boundary for territorial waters was derived from the distance a cannon could fire from the shore (Kent, 1954).

However, times have changed since a cannon measured states' governmental control over maritime space. Steinberg (2001: 18) notes that 'although in the modern era the sea has been constructed outside the territory of individual states, it has been constructed as a space amenable to a degree of governance within the state system.' Specifically, technological change has enabled the sea to become more knowable, inscribable, and controllable (to tweak Schmitt). For instance, Havice (2018) traces a novel arrangement in which Pacific island states act collaboratively to collectively 
regulate fishing in their economic exclusion zones, but also de facto extend that regulation over portions of the high seas. To do this, they required fishing vessels 'to provide real-time spatial data on vessel location through on-board vessel monitoring systems. [Pacific island states] share these data with each other for region-wide monitoring and enforcement' (Havice, 2018: 1290). This is an example of how states can network their geospatial data and enforcement apparatuses to shape maritime space. The military term for this networked capability is interoperability, which refers to

the ability for Allies to act together coherently, effectively and efficiently to achieve tactical, operational and strategic objectives. Specifically, it enables forces, units and/or systems to operate together and allows them to share common doctrine and procedures, each other's infrastructure and bases, and to be able to communicate. (NATO, 2017: n.p.)

That is, interoperability speaks to the need to fold allied military organizations into one another, opening up perhaps the most quintessentially 'national' institution to transnational flows of information, fuel, ammunition, and bodies.

Between World War 2 and the Trump presidency, American defence policy worked to create a sense of Western-led collective security that has - for good or ill dominated world politics. Interoperability has underpinned this world order. Since the end of the Cold War, the North Atlantic Treaty Organization (NATO) has expanded its remit from mutual defence to include 'out-of-area' operations in places such as Bosnia and Afghanistan. A geographic expansion of interoperability enabled these out-of-area operations to occur in new ways, with standards declassified and countries like Algeria, Bahrain, and Kazakhstan encouraged by NATO to adopt them and join in the zone of interoperability. Thus, ad hoc coalitions could be formed in short order 
to counter the increasing unpredictability of post-Cold War crises, such as when Uzbekistan served as a base for air strikes in the 2001 invasion of Afghanistan. Therefore, we can see how interoperability - as wielded by the US and its allies in recent years - is an effort to produce a global smooth space through which Western military forces can operate with few technical limitations (see also Moore and Walker, 2016). The remainder of this paper focuses on a specific Pentagon-led project that seeks to produce naval interoperability around the world, enabling ad hoc coalitions to be formed: the Global Network of Navies (GNoN).

As we shall see, the GNoN project is geopolitically advantageous in advancing American interests (or so the Pentagon believes), but I want to argue that it is more than that. It must also be understood as an attempt to render the ocean more amenable to statist governance and intervention (see Elden 2009). The GNoN furthers this through the production of interoperability between states' ports, navies, and paramilitary naval forces, enabling data to flow on a global scale; this interoperability is intended to render the ocean itself amenable to state action by creating a global 'Maritime Domain Awareness'. This requires us to hold in mind simultaneously a traditional, U.S.-centric hegemonic geopolitics and a more de-centred geo-politics of 'the state' that seeks to produce maritime space of, and for, a globally aspirant transnational state assemblage. In this paper, I make three related arguments. First, I argue that the GNoN is an attempt to produce ocean spaces within a U.S.-led, but ultimately transnational, state assemblage. Second, I argue that this project relies on the materiality of the sea to affectively nudge forward transnational cooperation among navies that are potentially rivals. Third, I argue that this reliance on the materiality of the sea is paradoxical, as the GNoN attempts (and ultimately fails) to dematerialize ocean space into abstract network ontology. 
In the next section of the paper, I engage in a detailed theorization of military interoperability through the language of assemblage. Assemblage thinking is particularly useful here not only in terms of how it enables states to be understood as always already in relation to one another, but also because it allows for a consideration of the materiality of the sea and the way it affects states. For instance, I argue that naval cooperation is one of the most frequent, and non-controversial, ways in which foreign policy apparatuses become enmeshed with one another. I then produce a genealogy of the relationship between maritime space and naval technologies, with a special focus on the U.S. Navy.

I then follow this discussion by critically reviewing the scholarly and 'grey' literature on the GNoN, in order to zoom in on the contemporary interplay of space, C4ISR technology, and geopolitics with respect to the maritime environment. I supplement this critical review with two (anonymised) elite interviews with retired US Navy personnel who were deeply involved in the cultivation of naval interoperability, one at the policy level (Interviewee 1) and one as a practitioner (Interviewee 2). These interviews served to ground the policy discussions of the literature in the lived experience of naval life, providing an important corrective to some of the overly optimistic GNoN boosterism in the literature. First, I detail the role of interoperable C4ISR technology in producing the GNoN assemblage, and overcoming the challenges of creating flows of data at sea. While interoperability seems innocuously technical, it embeds within it a politics. Second, I attend to how maritime space is produced in relation to this assemblage. Despite the Pentagon's effort to dematerialize the ocean into a network ontology, specific sea configurations recur within the GNoN assemblage. Finally, I conclude by highlighting the 
implications of this study for scholars of assemblage, the state, and the broader material turn in geography.

\section{Assemblage, interoperability, and the transnational state}

Assemblages have been defined as open 'wholes characterized by relations of exteriority' (DeLanda, 2006: 10), and they offer a way of re-thinking geography through a flat(ter) ontology (Marston, et al., 2005). I say 'flat(ter)' because while assemblage denies the a priori existence of scales, it sees them as emergent effects of translocal processes of assemblage. For instance the power and authority of the state can emerge 'above' an individual, but ultimately, it must be instantiated and materialized in place through some element of the state assemblage. Because they are open wholes, and embedded in relations, assemblages are capable both of affecting, and being affected. That is, elements in an assemblage are changed - however subtly - by their relation to the other parts of the assemblage. Müller (2015) argues that an assemblage bears five characteristics, which I will explicate here with reference to the state and its military apparatus.

First, all assemblages are fundamentally open, and therefore only understandable in relation to other assemblages. Indeed, one of the utilities of assemblage theory is in how it allows for affect-driven dynamism to ripple through multiple assemblages in ways difficult to predict. For instance, militaries require constant and substantial influxes of funding in order to maintain standing forces. Therefore militaries remain linked to the broader economies that sustain them, and the political systems that allocate scarce tax money. Military readiness can appear stable through these ups and downs but eventually may reach a tipping point in which certain military capabilities dissipate. 
Second, assemblages are constantly becoming otherwise. The process of elements entering into, or departing, the assemblage of the state is referred to by DeLanda (2006) as territorialisation and deterritorialization. These should be understood as concurrent processes, rather than overall descriptors of the state of the assemblage (excepting complete deterritorialization, when an assemblage ceases to exist). For instance, militaries are dependent on a constant stream of recruits to embody the military, and similarly aging equipment must be replaced and, if possible, upgraded. Frequently these processes intersect, for instance as when more women have been incorporated into combat roles, necessitating changes in equipment design.

Third, assemblages are composed of heterogeneous elements. Social assemblages include, at a minimum, a set of human bodies that are in relation to one another, and they can be embedded in a discourse. However, the relations are always excessive of 'just' discourse. The military is therefore understandable as a collection of many bodies, things, and discourses: the aforementioned equipment and recruits' bodies, as well as personnel records, discourses of heroism and sacrifice, strategy documents, geospatial data, secret intelligence, stockpiles of fuel and ammunition, and so on. These objects, bodies, and discourses come together to produce something greater than the sum of their parts; a new agency emerges that is capable of unleashing great violence.

Fourth, because assemblages are open to relations, they are impossible to strictly define. Having said that, processes of coding work to define, delineate, and attribute meaning to the assemblage. The state has historically been an overcoded assemblage, with a general assumption that it is 'out there' and distinguishable from non-state actors. However, scholars have sought to demonstrate how that binary of state/non-state is less clear in practice than in theory (Painter 2006; Jeffrey, 2012; 
McConnell, 2009). Here, a military reference point would be the role of the private sector in producing military equipment in close cooperation with the U.S.

Government. Companies like Northrop Grumman and General Dynamics serve as exclusive vendors of American military might, with military staff frequently retiring and going directly to work in this 'private' sector.

Finally, assemblages have desire, or immanent forces of self-organization. That is, they need not have an external stimulus for internal change to occur. An example from the military field- relevant to this argument - is the increasing complexity of weapons over time, which results in a 'baroque arsenal' (Kaldor, 1981) that requires top-down intervention to produce interoperability among weapons systems. Collectively, assemblage theory offers a useful account of the state that problematizes the unitary 'will to power' that sovereignty tends to embed in accounts of the state:

The state now appears simply as one element - whose functionality is historically specific and contextually variable - in multiple circuits of power, connecting a diversity of authorities and forces, within a whole variety of complex assemblages. (Rose, 1999: 5)

Indeed, just as Rose tends to highlight the plurality of 'wills to power' in any regime of governmentality, the world of states is de-centred with many different state (and other) apparatuses enmeshed with one another, and with various materialities as well. Of particular interest to this paper is the enmeshing of the state(s) with the sea, and the ways in which the sea troubles states' efforts to exert agency over the maritime domain. In the next section, I theorize the coming together of naval forces to exert state power over the sea through the lens of assemblage. 


\section{Interoperability and the transnational state at sea}

Foreign policy apparatuses are always also in assemblage with those of other states, most obviously through diplomatic relations. However, the points of connection for some relations range far beyond ambassadorial exchange; a wide array of material connections link together allied foreign policy (and other) apparatuses, from shared signals intelligence databases to secure communication systems, and even co-located embassies (Dittmer, 2017; Uilenreef, 2014). These points of connection enable affective relations to form between state foreign policy apparatuses, allowing events occurring in one state assemblage to ripple through other states. Instead of a foreign policy apparatus just acting in the world, the world is always already acting on that apparatus, shaping the subjectivities of the elites charged with making policy. Therefore, we can point to a transnational state agency that - although it is global in aspiration (if not in reality), is highly geographically uneven in its intensity. This agency has potent subject-forming powers that re-work state elites' subjectivities.

This transnational state, composed of and operating through other states, is precisely what Admiral Mullen was counting on cultivating in his initial outline of the GNoN. As discussed in the introduction, multinational interoperability refers to the process through which military organizations are folded into one another, producing a new capability (NATO, 2017). National militaries design their equipment and train their people so that they can work together in a battlespace, producing the capability to - for instance - land a jet on an aircraft carrier. However, if two national militaries attempt to do the same thing - for instance if a South Korean pilot tries to land her jet on an American aircraft carrier, that capability may not be reproduced. Producing interoperability of this sort requires material design and the ongoing training of personnel. 
Interoperability has a specific history rooted in the history of military technology. The technological innovation that made World War 1 the bloodiest war in history posed new problems to be overcome by additional innovation. For instance, the invention of the machine gun led to trench warfare, which led to the invention of the tank (Wright 2000). As new technologies were territorialized into the national military, they undermined the coherence of that military, in that the supplies and mechanical expertise needed to maintain the specialist equipment were highly idiosyncratic. As an example, land-based aviation and sea-based aviation were maintained as separate weapons systems by many armies and navies, undercutting fighting effectiveness (Barry and Blaker, 2001). Even within militaries, then, it takes a great deal of on-going work to minimize the divergence of weapons systems where possible. However, the rise of (thus far) permanent alliances such as NATO after World War 2 added the challenge of multinational interoperability. The fluid alliance system that dominated European imperial geopolitics had meant that any current ally could soon be an opponent, and so technical capabilities, logistical systems, and other facets of the technological estate ought to be maintained as secrets even while collaboration was ongoing. The new logic of permanent alliance, however, emphasized the existential need to harmonize equipment and practices with allies to produce a coherent and effective fighting force. Allied militaries would have to reterritorialize around standard equipment and re-code the bodies of soldiers and sailors to follow similar procedures (Dittmer, 2017).

However, what Admiral Mullen proposed was fundamentally different than a large-scale, permanent alliance like NATO. Rather, as said earlier he proposed 'an open and adaptive architecture for facilitating both long-term cooperation and spontaneous, short-lived collaboration' without any treaty (Greenert and Foggo, 2014: 
n.p.). In other words, Mullen was calling for interoperability among the world's navies, absent the comradeship of permanent alliance and the trust it engenders. Nevertheless, the GNoN harnesses alternative affective currents to predispose partners to cooperate. First, the materiality of the sea itself provides an affective nudge, as the longstanding traditions of mariners, engendered over centuries of seafaring, emphasize mutual aid in the face of a hazardous, and fundamentally inhuman environment. That is, the very molecular composition of the sea - as 'loose particles' - that enables ships to move heavy loads cheaply over long distances also makes it a dangerous environment for vulnerable human bodies (Peters 2014: 423). In fact, Lawrence (2015: 1) describes the sea as inherently 'internationalist': 'tracing back to the earliest observations that some aspects of operating at sea are universal namely, that seafarers share common hardships and opportunities that predispose navies to collaboration.' The same view was voiced in one of my interviews:

It's an old cliché, but the old story of people who go out to sea in ships. [...] The ship captains — they have a bond. They've all had a man overboard, they've all faced a storm. They've all had to deal with engineering casualties. They've all had to tow somebody. They've all had to rescue someone from sea.

It is noteworthy that those narrating the GNoN describe as its foundational event not something military, but humanitarian: the December 2004 tsunami (Kraska and Wilson, 2009). This narrative of an already-existent proto-GNoN, inherent in the affective bonds of those at sea, is powerful among mariners. As one interviewee said, 'the sea itself provides a medium for cooperation.' When combined with the anxious representation of the ocean as a threatening space in need of state governance, it becomes clear that there are powerful state affects at work. 
Second, its advocates highlight the discourse of the high seas as a Global Commons (Hannigan, 2016) best managed collectively (rather than by a hegemon):

Lower-intensity maritime threats, such as maritime terrorism, narcotics smuggling and human trafficking, and piracy and armed robbery at sea, are corrosive to regional stability. Illegal, unreported and unregulated fishing, the exposed containerized shipping, the vulnerability of bulk and liquified cargo to attack - and environmental catastrophe - and preventing infiltration of the global seafarer workforce by criminal and terrorist organizations, all pose maritime security threats with global implications. (Kraska and Wilson, 2009: 226)

As Cowen (2010: 131) noted, 'Precisely because piracy is a crime that occurs outside the authority and territory of any singular national authority, the pirate has long been a figure that is constituted by the geographies of (national) sovereignty but also fundamentally troubles them.' The other threats described - terrorism, drug cartels are similar non-state actors who act in defiance of the territorial/terrestrial logic of sovereignty. One might now, tragically, include refugees in this category (CasaCortes, Cobarrubias, and Pickles, 2016). Therefore, they can be perceived as an existential threat to states, collectively.

In this section I have conceptualised interoperability through assemblage theory and traced how a transnational state agency can work in and through material relations, including relations with the sea itself. The GNoN is a particular challenge, in that this interoperability has to be fostered in the absence of permanent alliance and the trust it engenders (cf Barry, 2001). However, the maritime context itself provides the affective nudge that jumpstarts cooperation within the GNoN. This affective nudge is a very different way of thinking about the role of the sea in the 
(re)production of state space and its geopolitics than has been considered in the past, when land and sea were understood to be determinative of geopolitical outcomes. In the next section, I turn to this genealogy of ideas and technologies, which has led to today's GNoN project.

\section{Maritime space and U.S. naval technology}

In this genealogy, I would like to emphasize the role of naval technologies in mediating the sea's materiality to produce maritime space. Efforts to survey and governmentalize maritime space - and the challenges to those efforts posed by the sea's materiality - have not received nearly enough attention (cf Peters, 2010). Indeed, the origins of the assemblage-like GNoN can be found in one of the foundational texts of classical geopolitics. Mahan (1890) advocated the expansion of the U.S. Navy by tracing the strategic importance of sea power in shaping past geopolitical orders. Mahan's argument was successful in shaping U.S. policy, and not coincidentally narrowly precedes the shift in American empire-building from a continental frame ('Manifest Destiny') to a trans-oceanic one (e.g., the 1898 SpanishAmerican War). Of course, Mahan's ideas were not invented from thin air; the contemporary model for this kind of sea power was the Royal Navy, whose sea power led to victory in the Napoleonic Wars and then to the so-called Pax Britannica. Mackinder's (1904) reversal of Mahan's theory of sea power highlighted new technological shifts (such as the trans-Siberian railway) that potentially left sea powers vulnerable to being outflanked by increasingly mobile land powers. In giving voice to the anxieties of imperial decline, Mackinder opened up the role of technology in sustaining (or threatening) the strategic value of specific geographic features. 
Crucially though, he left the land/sea binary intact and agreed that they were antithetical to each other.

Changing naval technologies also underpinned the rise of the U.S. Navy into a force capable of projecting force globally. Whereas pre-Mahan the U.S. Navy had been composed largely of fast-moving frigates and fairly limited to continental and Caribbean concerns (for instance in raiding British trade in the War of 1812 and blockading Southern ports during the Civil War), the period between the SpanishAmerican War and World War 1 left the United States with a fundamentally different Navy. This period saw the rise of the ironclads and eventually dreadnaughts and battleships (Sondhaus, 2001). A key event in this transition was the sailing of Teddy Roosevelt's Great White Fleet around the world from 1907-1909. As a form of naval diplomacy, the Great White Fleet - composed of sixteen battleships and accompanying vessels - called at friendly ports all over the world in a performance of newfound naval capability and geographic reach (Crawford, 2008). The advent of the American 'blue water' navy (i.e., one that operates over long distances) and the sinking of the Lusitania in 1915 ended the period in which American naval power would see itself as at most a potential king-maker in a European conflict, and began a new period in which the U.S. sought naval dominance on its own (Rubel, 2013). This was, to some extent, the fulfilment of Mahan's vision; the U.S. Navy, by the end of World War 2, had replaced the Royal Navy as the arbiter of ocean spaces, although it maintained the British view of free trade and, consequently, mare liberum.

One dimension of American naval power that Mahan could not have foreseen was the rise of naval aviation. World War 2 demonstrated the eclipse of the battleship by the aircraft carrier (Williams, 2017). With both Mackinder's concern over the ability of land power to strike at the coasts of Eurasia and also newfound concerns of 
Communism spreading around the edge of Eurasia like dominos (O'Sullivan, 1982), the scene was set for the U.S policy of containment. Containment was rooted in Spykman's (1942) concept of the Rimland, or the contested space between the Eurasian land powers and the sea power of the 'outer islands': Western Europe, Arabia, India, Indochina. If containment was the geopolitical concept that dominated the Cold War, the aircraft carrier was containment's naval technology par excellence. Aircraft carriers not only allowed naval power to move even more quickly into position where needed, but also allowed for the quick projection of military force far inland wherever needed in the so-called Rimland. The blurring of sea and land power represented by the aircraft carrier is perhaps best indicated by the common refrain that the island of Great Britain is an 'unsinkable aircraft carrier' from which the United States can operate (Flint, 2016).

With the collapse of the Soviet Union, and therefore of any clear opponent, the U.S. Navy returned to a broadly Mahanian role as guarantor of the high seas, fostering a trade regime and world order that buttressed American hegemony. The naval term for this is 'constabulary duties', and although they are arguably foundational to American power, it is also distinctly unglamorous work for a force trained in 'highend' war fighting. Further, Rubel (2013) notes that the Navy struggled to respond to the 11 September 2001 attacks, in that patrolling the entire U.S. coast to prevent a hypothetical maritime terrorist assault threatened to pull an inordinate amount of naval assets into the littoral, and consequently undercut the naval presence required by the U.S.'s occupations of Afghanistan and Iraq.

The solution to this double conundrum was found in the recognition that a line of naval vessels up and down the coast could not defend the 'homeland' from maritime terrorist attack, and such an effort would undermine U.S. naval power in 
other ways. A forward defence was required, and this would hinge on intelligence gathering and cooperation with partners.

These in turn would require the cooperation of as many foreign navies, coast guards, and other agencies as possible. That consideration led to the notion of a global maritime partnership, but political conditions obviated an extension of existing alliances or the creation of new ones. The answer was found in the crafting of a new maritime strategy document that articulated a universal maritime mission - defence of the global system of commerce and security. (Rubel, 2013: 18)

And thus was born the concept of the 1000-Ship Navy, as it was originally dubbed by Admiral Mullen in 2006. The program's name proved controversial, as its singularity implied that the world's navies were going to be seconded to the U.S Navy. It was almost immediately redubbed the Global Maritime Partnership, and as that still sounded too centralized it was again renamed the Global Network of Navies in 2014. The shift in nomenclature parallels the shifting geographies of the state outlined in the previous section, from stand-alone sovereignty to a transnational state assemblage: '[T] he retitling of the concept is more than merely cosmetic. It suggests a significant move away from the traditional 'modern' thinking that probably explains the label originally given to the concept,' (Till, 2008: 28) The plural-ness of this label is mirrored in the envisioned assemblage-like architecture:

The value of a Network of Navies is that it provides an open and adaptive architecture for facilitating both long-term cooperation and spontaneous, short-lived collaboration. [...] Individual navies can 'plug in' to nodes of the network when it serves their interests, and then expand, contract, or otherwise alter their participation when it suits them. [...] The only requirements are a 
willingness to collaborate and the creation of a network that is scalable, durable, responsive, flexible, and interoperable. (Greenert and Foggo, 2014: n.p.)

The GNoN, with its topological imagination of material connections and affective relations, and its fundamentally scale-less spatiality, is a quintessential example of an assemblage. Ships and sailors can be territorialized into a coalition on short notice, and afterwards can be deterritorialized; yet the training and equipment necessary to be interoperable changes those who are even virtual participants. In the next section, I turn to the specific technical challenges posed by interoperability at sea, and the political affects and effects that accompany proposed solutions.

\section{Technological co-evolution and differentiation}

While classical geopolitical approaches to sea power considered technological change, the focus remained on the properties of the sea rather than the capabilities forged by specific maritime technological assemblages. An assemblage approach to the GNoN avoids the determinism of past formulations by requiring an empirical investigation of the specific technological relations that bring things and bodies, and the sea into assemblage with one another. In this section I examine the technological challenges of interoperability at sea, with a particular emphasis on how the vastness of ocean space is to be made sensible and sense-able by transnational naval forces.

Naval interoperability can take place in a variety of ways, from the general outline of plans to stay out of each other's way, to the form of organisational integration currently practiced by the U.S. Navy and the Royal Navy (which have agreed to coordinate ship-building and other activities to avoid redundant capabilities - see Combined Seapower 2014). However, the GNoN proposes, as a starting point, 
temporary coalitions to conduct constabulary duties and humanitarian and rescue missions. These missions have specific interoperability requirements which are known in military circles as C4ISR, which refers to 'Command, Control, Communications, Computers, Intelligence, Surveillance, and Reconnaissance'; these are the technical systems that enable a naval commander to sense both the immediate and broader context (so-called 'Maritime Domain Awareness') as well as to enact agency over a naval assemblage at a distance.

When you're an officer of the deck and you come up to the ship at night and you're standing watch, your main job is just your immediate area — knowing who's who in the zoo — this ship is this ship, this ship is that ship — and making sure that your watch turnover is done correctly and that what you're seeing visually matches what you've got digitally. What are the display systems showing in the Combat Information Center? [...] And that's why Maritime Domain Awareness is so important, especially in areas of counterpiracy where we're sharing information. (Interviewee 1)

The ideal scenario here is so-called 'picture-based warfare' where commanders use a 'more-or-less real-time picture of what is happening' (Friedman, 2009: ix). When this is distributed across multiple ships (or navies) it becomes known as the 'Common Operating Picture'. This is the end goal of interoperability in the C4ISR realm.

The rise of jet-age warfare accelerated the pace of combat, putting strain on the ability of naval commanders to sense threats and respond in time. This led to new work on automated combat systems that would link together ships (and the U.S. Air Force) via ultra-high frequency (UHF) wireless 'tactical data links'. The Tactical Data Information Exchange System (TADIXS) proved useful for coordinating scattered naval assets. The technology evolved into the Link 11/16/22 C4ISR systems used by 
the Commonwealth/U.S. navies today (Hszieh et al., 2014). Link systems accommodate the rise of satellite communication technology and facilitate the ascendance of the 'network-centric warfare' concept, which goes beyond simple implementation of C4ISR technology to include 'the development of doctrine and associated tactics, techniques, and procedures that enable a force to develop and leverage an information advantage to increase combat power,' (Office of the Secretary of Defense, 2001, cited in Hszieh et al., 2014: 30). That is to say, the entire naval assemblage is affected by the introduction of these technologies, from discourses of strategy to the embodied training of sailors' and pilots' bodies. This capability relies on the ability to establish a real-time Common Operational Picture across allied forces. The challenge of the GNoN is to spread this across non-allied navies.

As in the history of interoperability discussed earlier, the central conundrum is in the different technological paths charted by different navies.

Many Commonwealth countries have worked together in the naval realm for decades, and have acquired technologies and practices which allow them to communicate seamlessly with each other and the US Navy. Often these navies choose what kit they will buy based on shared requirements, paying special attention to interoperability and on staying at the cutting edge of new technologies. (Bedford, Galdorisi, and Hszieh, 2010: 37)

In other words, some navies have co-evolved with C4ISR collaboration in their technological DNA. However, other potential members of the GNoN use off-the-shelf or second-hand C4ISR equipment. 'The more extensive the interoperability among [Commonwealth/USA] allies gets, the deeper the gulf separating the United States from its American continent and Caribbean partners becomes,' (Soto, 2010: 145-146). 
Related to the problem of technological differentiation is a general problem of data flows at sea. Put simply, as the growth of fibre optic cables around the world increased global data capacity exponentially in the 1990s and 2000s (Starosielski 2015), data demand of software has increased in parallel. However, naval vessels when at sea - are unable to partake of this technology, and instead are limited to wireless transmission, with limited bandwidth, and possibly a satellite uplink. Therefore, any attempt at network-centric warfare (especially in joint operations with land-based units who have the benefit of superior bandwidth) is inherently taxing on naval C4ISR data capacities (Hszieh, et al. 2014).

A related problem confronting the GNoN in the realm of C4ISR is data fusion and intelligence sharing. The ideal scenario for interoperability is one in which all information is shared with all partners to create the Common Operational Picture. 'This is a highly ambitious undertaking which will demand not only the application of technology but also the development of protocols and procedures, political and, at times, possibly legal arrangements for the accessing and sharing of data,' (Rahman, 2008: 27). However, as Lawrence (2015: 36) notes, 'it is an inescapable fact of life that there are different qualities of political trust and security relationships between states, which inevitably determines what information can be shared with a potential network partner and what can not.' The U.S., and its close allies such as the UK and Canada, freely share intelligence with one another (and have, for years, via the UKUSA pact - Dittmer, 2015). However, being in possession of more intelligence than its potential rivals is one of the tactical advantages that the U.S. has invested in heavily over many decades. Therefore, while the GNoN concept asks partners to contribute to the overall Maritime Domain Awareness through networking of sensors on ships (and ports, etc.), the U.S. in practice limits what it would be willing to share. 
Other states may well agree that their data is a sovereign resource not to be shared. Network structures are not devoid of political hierarchies. Further, there are many legal hurdles to the 'global' circulation of data, as much of the data collected by national agencies from (for instance) shipping companies and the like is tied up with confidentiality agreements (Lawrence, 2015).

The technological 'solution' used thus far to address this is the Combined Enterprise Regional Information Exchange System - Maritime (CENTRIXS-M). CENTRIXS-M, when installed in all participating naval vessels, allows for a graphically-displayed Common Operational Picture, sharing of intelligence, e-mail capability (with attachments), chat rooms, and even secure VoIP (i.e., Skype capability). The lowest-end version of CENTRIXS-M consists of just a laptop computer and a satellite phone, and can be installed in a boat of any size. Signals are bounced off of a satellite to (and from) a data fusion centre, usually run by the United States. CENTRIX-M threads the needle of intelligence sharing by functioning as 'multiple, unconnected networks, or coalition “communities of interest" (or enclaves)' (Rahman, 2008: 39). In other words, centrally held data is dispensed to participant navies based on pre-existing rules about whose intelligence can be shared with whom. The problem of this technology for GNoN is that the architecture assumes the centrality of the U.S. in the operation and builds in its data supremacy, whereas (as proposed) the GNoN is flexible and polycentric. Concerns about the intentions of the U.S. in engineering this assemblage are, for this reason, real obstacles. Part of the aim (from the Pentagon's perspective) is to envision 'burden sharing', which is to say missions without the U.S. at the forefront (or even involved).

To summarize, the GNoN is articulated as a highly technical engineering problem of overcoming the challenges of C4ISR at sea, but inside those technical 
challenges (data flows, data fusion) is embedded a topological architecture that locates the USA at the centre. In the next section I argue that this topological architecture has implications for our thinking about state territoriality and its relation to the materiality of the sea.

\section{Territory, Power, and the 'Global Network of Networks'}

Recent work has highlighted the role of drones in the reconfiguration of territory through military action (Gregory, 2011; Kindervater, 2017). These analyses have usefully highlighted the ways in which surveillance and military forces have remade territories. State sovereignty has become understood conceptually as topological, technological and temporary (Painter, 2010; Elden, 2013), erupting within other territorialities and then dissipating, because of its enmeshing with the US-led drone assemblage. This literature has questioned the fundamentally topographical imagination of state territory, but has done so within a predominantly terrestrial imagination of territory. The absence of work on state surveillance of the seas is a significant lacuna, as 'our world is a water world' (Anderson and Peters, 2014: 1) and, as discussed earlier, the ocean is the source of what are perceived to be existential threats to the ideal of stateness. The challenge of asserting sovereign power across that vastness has been relatively neglected in the political geography literature. One exception has been the work of Peters (2014), who notes that the sea provides a natural site from which to evade state regulatory practices. Here too, though, we see a tendency to think in terms of the state as a singular 'will to power', rather than - as discussed earlier - a transnational assemblage that seeks to order space by working through individual states, yet is not reducible to one (e.g., the United States). 
An exception is Shaw (2016), who asserts a shift from 'American Empire' to 'Predator Empire'. By this he means a shift from traditional geopolitical hegemony to a transnational (if U.S.-led) neoliberal enclosure of global life itself, facilitated by algorithmic technologies and surveillance. While of course aerial drones can and have been used for littoral surveillance, and the U.S. Navy created its first aerial drone squadron in 2018, they are still primarily conceptualised in terms of terrestrial surveillance: 'When the U.S. Navy fully exploits the fact that 98 percent of the world's land area rests within the flight orbit of TERN [a sea-based drone in development], the Predator Empire's reach will be boundless,' (Shaw, 2016: 146). The future is of course open, but drones have not yet revolutionised Maritime Domain Awareness in quite the same way that Shaw traces on land, because of the vast and fluid materialities of the ocean itself.

The Pentagon envisions the GNoN as an attempt to remedy this absence, extending the Predator Empire over the sea to produce Maritime Domain Awareness. However, the fate of the GNoN illustrates that Shaw's thesis is insufficiently attentive to the specific medium of the sea and the challenges it poses to American ambition. In this section I will therefore elaborate an argument parallel to Shaw's, while also flagging up the geopolitical materiality of the sea and its role in fragmenting the universal aspirations of the Pentagon.

On the one hand, the aim of the GNoN is straight-forwardly to share the burdens of global constabulary duties more evenly between the U.S. Navy and its partners to battle human trafficking, drug smuggling, pirates, and other purportedly universal threats to the state system. However, as discussed above this poses a technological problem to be surmounted: the production of C4ISR interoperability. As is often the case, the technical field masks an underlying politics. The quest for 
Maritime Domain Awareness operationalizes existing data in new ways that enact new power relations.

Having a Common Operating Picture to share with any partner around the globe on a moment's notice requires the U.S. Navy to have complete Maritime Domain Awareness. This is frequently described by the U.S. Navy as a maritime version of the International Civil Aviation Organization's system of global tracking of airliners via air traffic control. As Rahman (2008: 27-28) notes, however, there is an obvious safety interest in preventing airliners from colliding. There is no similar safety interest in globally tracking slow-moving, easily avoidable shipping vessels (local monitoring in straits and areas of high congestion is possible, and already done, without a global infrastructure). Further, the civil aviation initiative is organized by a UN organization, while this is a U.S. Navy initiative. 'Nevertheless, one of the [U.S. Navy]'s ongoing technology development programs involves the construction of an "unlimited track database" which would "merge and display" maritime track data from a number of separate databases.' This database would - if the intent were fulfilled - maintain real-time location and cargo information on the roughly 58,000 shipping vessels plying the high seas.

The data to fill this database includes post-9/11 data required by the United States for any ship landing in U.S. territory, but likely to become a global standard expectation. For instance, the Advance Electronic Cargo Information program requires any ship bound for the U.S. to provide its cargo manifest 24 hours prior to being loaded in a foreign port, allowing for it to be inspected overseas by U.S. Customs agents. Meanwhile, 96 hours away from the U.S. port, that same ship must send its voyage history and information about the cargo and crew (Cowen, 2014). The ship itself is continually both VHF radio broadcasting (Automatic Identification 
System, or AIS) and satellite uplinking (Long Range Identification and Tracking, or LRIT) its identity and tracking information, although this information is not subject to data fusion and therefore cannot be used for real-time Maritime Domain Awareness (Rahman, 2008). One fundamental change here would be the fusion of this civilianprovided data with military surveillance data, such as sonar data that was originally designed to track submarines coming and going through straits and maritime chokepoints but is now directed at civilian traffic.

The fusion of all this data is intended to produce Maritime Domain Awareness, which may (or may not) be dispensed to the U.S. Navy's partners through a Common Operational Picture. Crucially, it would also allow for algorithmic governance to identify potential threats: the comparison of historical tracks with a specific ship's track, or changes in cargo provenance, or even in individual crews (each crew member is required by the International Labour Organisation to carry a biometric ID card - Cowen, 2014). The aim of the U.S. Navy is nothing less than "the effective understanding of anything associated with the maritime domain that could impact the security, safety, economy, or environment of the United States," (National Plan to Achieve Maritime Domain Awareness, quoted in U.S. Navy, 2007: 4). However advantageous this program is for the United States, we should not be so cynical as to believe that other states will not benefit as well. The program is about governmentalizing the sea for state intervention, rather than merely being pro-United States.

Now, lest we imagine that the GNoN is - through its twin aims of producing global Maritime Domain Awareness and then linking partner navies through a Common Operational Picture and at-sea interoperability - fully enclosing the sea and universally folding it into the Predator Empire, I would like to introduce some 
geographical nuance. First, the initiative explicitly excludes submarines, whose raison d'être is to disappear into the oceanic depths. Therefore, the Maritime Domain is conceptualised as a topographical, rather than volumetric, environment (Steinberg and Peters, 2015). Further, it is notable that the term 'Global Network of Navies' appears to be in decline. Like the original moniker '1000-Ship Navy', it seems to have run aground on the scale of its ambition. Rather, one of my interviewees put it this way: 'That thing that you were reading is about the Network of Navies, but I think it's a Network of Networks.' (Interviewee 1, emphasis added)

The Network of Networks is a useful term, in that it avoids the universality of the global while aspiring to a more practical, tactical approach to naval interoperability. Given the fears of U.S. centrality to the GNoN, and the vulnerability of the system to bad-faith participants, the scale of the partnership could only ever go so far. Lawrence (2015) argues that the key characteristics of any partner in the GNoN are interoperability (of which we have been discussing), transparency, predictability, and capability. While the first refers to the technical capacity to work alongside one another, the second - transparency - refers to the practice of information sharing, which as we have seen is crucial to Maritime Domain Awareness. The third characteristic - predictability - is used by Lawrence to delineate those who adhere to the U.S.'s vision of the high seas from those who do not (specifically, China and Russia). The final characteristic - capability - refers to the actual ability of a partner to contribute in substance to burden sharing in constabulary or other duties.

Childs (2016) lists the inner circle of partners as the UK's Royal Navy, the Japan Maritime Self-Defense Force, the Royal Australian Navy, the Indian Navy, and the South Korean Navy. Lawrence (2015) includes the French Navy in that inner 
circle, and outlines a range of 'outer circle' partners: Italy, Spain, Sweden, Singapore, Canada, New Zealand, Brazil, etc. However, this imagery of concentric circles misses out on the actual practices through which interoperability is produced. It is not a UScentric imaginary, but rather a set of regional partnerships - or even triads. One interviewee explains:

This is my own personal opinion - but when you try to make these things too complex, these alliance systems, it becomes too unwieldy. There's a sweet spot with the trilateral thing - you could get this country and that country together and it would work. You know what I mean? It wasn't as hard to grab all these things together. You had something in common. Maybe it's that we can fly P-8s. Australia flies P-8s. India flies P-8s. U.S. flies P-8s. Maybe we could do a little anti-submarine warfare maritime surveillance patrol.

(Interviewee 1)

That is, the production of interoperability is fundamentally understood as less political than technical. Whereas a formal alliance can be attention getting, both in terms of domestic and international audiences, practicing anti-submarine warfare together can just be background noise.

Similarly, my other interviewee raised the practical nature of regional cooperation as a virtue in comparison to a Global Network of Navies.

Interviewee 2: You look at some of the Combined Task Forces in the Persian Gulf, CTF 150 or 151, those exist for specific purposes [anti-piracy]. At a tactical level they exist.

Dittmer: Is it more that it's regional — so the idea of a Global Network of Navies is rhetorically better, but in practice it's a bunch of regional navies and the US is a member of all of them which makes it a network. 
Interviewee 2: I would say that's the red thread through it all.

Here we can see the Network of Networks operating, with the U.S. Navy as a member of each regional network, disseminating interoperable technologies and procedures around the world - albeit unevenly, given the political, economic, and historical nature of each network. This has the added advantage of making the U.S. Navy simply one partner in each regional network, bringing more naval power but less regional knowledge than the local partners. Interviewee 1 pointed out the political importance of this posture:

I was a ship captain right? I saw us as being hull down on the horizon. When a ship comes over the horizon the first thing that you see is the superstructure, you see the sail areas that come over when you're on the bridge and you got your binoculars up. [The rest of the ship is still below the horizon.] That's called 'hull down' and I wanted to be hull down on the horizon - I wanted to be a promoter of these middle power coalitions, these [tri-laterals], these [bilaterals], help knit it together but not be so visible.

In practice, then, the GNoN seems to be evolving in a way that is - unlike the purported enclosure of Predator Empire, rather more uneven and fractured.

The shift from the Global Network of Navies to the Network of Networks is interesting for the reasons just articulated, but also because it reflects an attempt to discursively extract the military concept from the sea itself. In contrast to the 1000Ship Navy, the Global Maritime Partnership, or the GNoN, the (admittedly unofficial) appellation of the Network of Networks neglects to mention the naval or maritime context at all. This reflects the long-standing desire of states to render the ocean legible to terrestrial conceptualizations of territory and thus amenable to state intervention; the abstract topology of the network is entirely dematerialized, or relies 
on technologies to be made interoperable (such as the P-8 aircraft in the above quote). However, the sea reasserts itself in the actual formation of triads; these triads are oriented around specific seas or oceans, with the U.S. as the 'global' participant. For instance, in the above quote about P-8 interoperability the Indian Ocean is the tacit context of the assemblage. Further, as discussed earlier, the sea provides both the material impediments in C4ISR interoperability (limited data flows and data fusion) and the (thus-far) insurmountable scale of the challenge for Maritime Domain Awareness. For these reasons, and the need to keep the U.S. 'hull down' in the eyes of its potential partners and rivals, the ambition to Maritime Domain Awareness remains fragmented and partial. We might think of it instead as Awareness of Maritime Domains.

\section{Conclusions}

Conceptually, this paper has attempted to move past theorization of the state as a toplevel apparatus or assemblage, and to consider the material relations between state apparatuses as an assemblage itself. This is not entirely new (Dittmer, 2016) but this paper goes further by considering this transnational state assemblage and its attempt to enfold the materiality of the sea into its territory. This provides a vocabulary for thinking of the interaction between state(s) and environment that avoids the determinism of Mahan and Mackinder, but nevertheless brings together state apparatuses, environments, and technologies into relation such that specific geopolitical spaces emerge.

Indeed, the materiality of the sea emerged in this analysis as 1) the problem to be solved by the states assembling the GNoN, 2) the affective nudge legitimating its politics, 3) the barrier that thwarted the creation of a truly Global Network of Navies, 
and 4) the material connection that justifies the U.S. Navy's bilateral and trilateral interoperability partnerships in the 'Network of Networks'. Despite the efforts of the U.S. Navy and its partners to governmentalize the sea, the state effects/affects of the GNoN remain fragmented and partial at best. These findings resonate with those of Steinberg and Peters (2015: 260-261):

The ocean, as we have argued - through its material reformation, mobile churning, and nonlinear temporality — creates the need for new understandings of mapping and representing; living and knowing; governing and resisting. Like the ocean itself, maritime subjects and objects can move across, fold into, and emerge out of water in unrecognised and unanticipated ways.

In this study the sea's materiality refers less to the depth and turbulence highlighted by Steinberg and Peters, and more to its vastness and the challenge that its liquidity poses when entering into assemblage with C4ISR infrastructures. Nevertheless, the sea also facilitates the assemblage in other ways, as its hazardousness underpins the affective nudge that brings all mariners together as a community and justifies the 'hull down' bilaterals and trilaterals.

\section{Bibliography}

Anderson J and Peters K (Eds) (2014) Waterworlds: Human geographies of the ocean. Farnham: Ashgate.

Barry A (2001) Political Machines: Governing a technological society. London: Bloomsbury.

Barry J and Blaker J (2001) 'After the Storm: the growing convergence of the Air Force and the Navy,' Naval War College Review 54(4): 117-133.

Bedford C, Galdorisi G, and Hszieh S (2010) 'The Interoperable Navy: Networking at sea,' Canadian Naval Review 6(3): 37-38.

Casa-Cortes M, Cobarrubias S and Pickles J (2016) "Good neighbours make good fences': Seahorse operations, border externalization and extraterritoriality,' European Urban and Regional Studies 23(3): 231-251. 
Childs N (2016) ‘The Measure of Britain's New Maritime Ambition,' Survival 58(1): 131-150.

Combined Seapower (2014) 'A shared vision for Royal Navy-United States Navy Cooperation.' Available online at http://www.navy.mil/docs/RN-

USN\%20Combined\%20Strategic\%20Narrative\%20CNO-1SL\%20Signed.pdf (Last accessed 19 July 2018).

Crawford M (2008) The World Cruise of the Great White Fleet: Honoring 100 Years of Global Partnerships and Security. Washington, DC: Naval Historical Center.

DeLanda M (2006) A New Philosophy of Society: Assemblage theory and social complexity. London: Continuum.

Dittmer J (2015) 'Everyday diplomacy: UKUSA intelligence cooperation and geopolitical assemblages,' Annals of the Association of American Geographers 105(3): 604-619.

Dittmer J (2016) 'Theorizing a More-than-Human Diplomacy: Assembling the British Foreign Office, 1839-1874,' The Hague Journal of Diplomacy 11(1): 78-104.

Dittmer J (2017) Diplomatic Material: Affect, assemblage, and foreign policy. Durham, NC: Duke University Press.

Elden S (2009) Terror and Territory: the spatial extent of sovereignty. Minneapolis: University of Minnesota Press.

Elden S (2013) 'Secure the Volume: Vertical geopolitics and the depth of power,' Political Geography 34: 35-51.

Flint C (2016) Geopolitical Constructs: the Mulberry Harbours, World War Two, and the making of a militarized transatlantic. Lanham, MD: Rowman and Littlefield.

Friedman N (2009) Network-Centric Warfare: How navies learned to fight smarter through three World Wars. Annapolis: Naval Institute Press.

Greenert J and Foggo J (2014) 'Forging a Global Network of Navies,' Proceedings Magazine 140(5). Available online at https://www.usni.org/magazines/proceedings/2014-05/forging-global-network-navies (Last accessed 22 June 2018).

Greenert J and Zambellas G (2014) 'Combined Seapower: A shared vision for Royal Navy-United States Navy Cooperation.' Available online at http://www.navy.mil/docs/RN-

USN\%20Combined\%20Strategic\%20Narrative\%20CNO-1SL\%20Signed.pdf (Last accessed 22 June 2018).

Gregory D (2011) 'The everywhere war,' Geographical Journal 177(3): 238-250 
Hannigan J (2016) The Geopolitics of Deep Oceans. Cambridge: Polity.

Havice E (2018) 'Unsettled Sovereignty and the Sea: Mobilities and more-thanterritorial configurations of state power,' Annals of the American Association of Geographers 108(5): 1280-1297.

Hszieh S, Galdorisi G, McKearney T, and Sutton D (2014) Networking the Global Maritime Partnership. Canberra: The Sea Power Centre.

Jeffrey A (2012) The Improvised State: Sovereignty, performance and agency in Dayton Bosnia. Chichester: Wiley-Blackwell.

Kaldor M (1981) Baroque Arsenal. London: Deutsch.

Kent, H. S. K. (1954). 'The Historical Origins of the Three-Mile Limit'. The American Journal of International Law 48(4): 537-553.

Kindervader KH (2017) 'Drone Strikes, Ephemeral Sovereignty, and Changing Conceptions of Territory.' Territory, Politics, Governance 5(2): 207-221.

Lawrence M (2015) Tailoring the Global Network for Real Burden Sharing at Sea. Lanham, MD: Rowman and Littlefield.

Mackinder H (1904) 'The Geographical Pivot of History,' The Geographical Journal 23(4): 421-437.

Mahan AT (1890) The Influence of Sea Power on History, 1660-1783. Boston: Little, Brown, and Co.

Marston S, Jones JP and Woodward K (2005) 'Human Geography Without Scale,' Transactions of the Institute of British Geographers 30(4): 416-432.

McConnell F (2009) 'De facto, displaced, tacit: The sovereign articulations of the Tibetan Government-in-Exile,' Political Geography 28(6): 343-352.

Moore A and Walker J (2016) Tracing the US military's presence in Africa. Geopolitics 21(3): 686-716.

Müller M (2015) 'Assemblages and Actor-Networks: Rethinking socio-material power, politics and space,' Geography Compass 9(1): 27-41.

NATO (2017) 'Interoperability: Connecting NATO forces,' Available online at https://www.nato.int/cps/ic/natohq/topics_84112.htm (last accessed 15 June 2018).

Office of the Secretary of Defense (2001) Network Centric Warfare: Department of Defense Reports to Congress, Washington: Department of Defense.

O’Sullivan P (1982) ‘Antidomino,’ Political Geography Quarterly 1(1): 57-64. 
Painter J (2006) 'Prosaic Geographies of Stateness,' Political Geography 25(7): 752774.

Painter J (2010) 'Rethinking Territory,' Antipode 42(5): 1090-1118.

Peters K (2010) 'Future promises for contemporary social and cultural geographies of the sea,' Geography Compass 4(9): 1260-1272.

Peters K (2014) 'Tracking (Im)mobilities at Sea: Ships, boats and surveillance strategies,' Mobilities 9(3): 414-431.

Rose N (1999) Powers of Freedom. Cambridge: Cambridge University Press.

Rubel R (2013) 'National policy and the post-systemic navy,' Naval War College Review 66(4): 10-29.

Schmitt C (2003) The Nomos of the Earth: the International Law of the Jus Publicum Europaeum. New York: Telos

Shaw I (2016) Predator Empire: Drone warfare and full spectrum dominance. Minneapolis: University of Minnesota Press.

Sondhaus L (2001) Naval Warfare, 1815-1914. London: Routledge.

Spykman N (1942) America's Strategy in World Politics: The United States and the Balance of Power. New York: Harcourt, Brace, and Co.

Starosielski N (2015) The Undersea Network. (Durham: Duke University Press).

Steinberg P (1999) 'Navigating to multiple horizons: towards a geography of oceanspace’. Professional Geographer 51(3): 366-377.

Steinberg P (2001) The Social Construction of the Ocean (Cambridge: Cambridge University Press).

Steinberg P (2009) 'Sovereignty, Territory, and the Mapping of Mobility: a view from the outside,' Annals of the Association of American Geographers 99(3): 467-495.

Steinberg P and Peters K (2015) 'Wet Ontologies, Fluid Spaces: Giving depth to volume through oceanic thinking.' Environment and Planning D: Society and Space 33(2): 247-264.

Till G (2008) 'A Cooperative Strategy for $21^{\text {st }}$ Century Seapower: A view from outside,' Naval War College Review 61(2): 25-38

Uilenreef A (2014) 'Alternatives to the Resident Embassy: Intra-EU diplomatic networks in the twenty-first century,' Diplomacy and Statecraft 25(2): 356-377.

U.S. Navy (2007) Navy Maritime Domain Awareness Concept. Available online at http://www.navy.mil/navydata/cno/Navy_Maritime_Domain_Awareness_Concept_FI NAL_2007.pdf (Last accessed 7 July 2018). 
Williams A (2017) 'Aircraft carriers and the capacity to mobilise US power across the Pacific, 1919-1929,' Journal of Historical Geography 58: 71-81.

Wright P (2000) Tank: The progress of a monstrous war machine. London: Faber. 